\title{
What should learning designers learn?
}

\author{
Keith Heggart $^{1}$ (D) . Camille Dickson-Deane ${ }^{1}$
}

Accepted: 9 June 2021 / Published online: 30 June 2021

(c) The Author(s), under exclusive licence to Springer Science+Business Media, LLC, part of Springer Nature 2021

\begin{abstract}
There is widespread interest in employing designers who focus on learning, performance and education technology in many industries at a global level. In Australia, learning designers are in demand in Education, Corporate Training, Finance, Charity, Non-Government Sectors, and also in Start-Ups and Entrepreneurial arenas. This demand is despite the fact that the role of the Learning Designer is incredibly varied, contextually-based, and also unclear to many employers - and students! This suggests that there is currently an opportunity for learning designers and academics who deliver learning design content to define what it means to be a learning designer. This paper presents an Australian case study which uses designbased research methods in a pre-production mode to identify the key principles that informed the development of a course of study (what others may refer to as a program). How those principles were operationalised within the course design and more are discussed in an effort to reposition understandings of knowledge, skills and abilities for this field.
\end{abstract}

Keywords Course design · Learning design · Higher education · Instructional design · Curriculum

\section{Introduction}

COVID19 has presented workforces across the world with many challenges. In Australia, the effects of the pandemic have been felt especially in the higher education sector, where many universities have announced the need to cut significant numbers from their workforces (Zhou, 2020). This is expected to fall on both academic and professional staff, and has been prompted, at least in part, by the decreasing numbers of international students enrolling in Australian universities due to travel restrictions. China is the largest contributor of international students to Australia's higher

Keith Heggart

keith.heggart@uts.edu.au

1 University of Technology Sydney, Ultimo, Australia 
education sector (Deloitte Access Economics, 2015) and thus a huge asset to the educational economy in Australia. During this time, it might seem strange to suggest that there are opportunities for learning designers in this space, but that certainly appears to be the case. While we are not entirely certain that a learning designer is 'the hottest job in higher education', (Decherney \& Levander, 2020), the pandemic has meant that universities are increasingly interested in online-only or high-end blended (Laurillard, 2013) models of learning. Nor are universities the only ones interested as primary and secondary schools have embraced (or been forced to embrace) the use of the online space for learning, and so too have organisations with training arms and separately training organisations within corporate sectors. In the space of half a year, it seems that everybody is now a user of digital technologies like Zoom and learning management systems but navigating this new space is not easy, especially if one has limited or no experience of using these environments. This means that there are opportunities for those in the learning design field especially those with expertise in the digital technologies and online spaces to work with subject matter experts and other professionals (including educators and trainers) in order to provide students with the best possible experience in these times-and in the future, too.

Even before the arrival of COVID19, there was a growing interest in the role of the learning designer (Slade, 2018). The term learning designer is used here synonymously with a range of different roles all of which combine and permutate descriptors to create a position title or define a role. Some descriptors used in this field include instructional, academic, developer, learning, engineer, educational, designer, technology and specialist. While there is acknowledgement that there may be perceived differences in these roles, the differences are often elided, or ignored completely in terms of practice. As such, the term "learning designer" and "instructional designer" will be used interchangeably to refer to all those whose main purpose is to design experiences where learning or performance is the primary outcome.

According to Seek.com (one of Australia's largest job search sites), jobs in the learning design field are expected to grow rapidly. It is estimated that in the next five years global opportunities in the learning design field will be up by $28.6 \%$ whereas in Australia the increase is still significant with 13.6\% (Seek.com, 2020). This is certainly evidenced by demands for learning designers in similar job websites. Another interesting point is that these demands are coming from a wide range of sectors. While tertiary education is a significant contributor, there are calls for learning designers in many other sectors, including but not limited to professional bodies (for example, the Royal Australian College of Surgeons), sporting groups (Australian Football League), government agencies (New South Wales Health, Transport for New South Wales), restaurants (Guzman Y Gomez) and many others, including banks, charities, and pre-tertiary schools.

This interest has raised older questions about the field of learning design. It is well-known that defining what a learning designer does is a challenge (Rieber, 2018a, 2018b; Wagner, 2011). There is confusion about the differences between the role of learning designers and teachers, but also with many of the other design professions, especially graphic and multimedia designs. This is nowhere better illustrated than in the Australian and New Zealand Standard Classification of 
Occupations (2019), which has no profession listed for learning designer; the closest is perhaps graphic and web designer (although there is a very brief note about a specialisation of instructional designer).

Questions about the role of learning designers and specifically what they actually should do naturally lead into discussions about how best they should be trained. These questions are not entirely unfamiliar or uninvestigated as both Rowland (1992) and Tripp (1994) have discussed how instructional designers should learn in situ. They surmise that learning should occur via a range of approaches which include some form of studio/practice-based activities as opposed to more traditional, classroom-based approaches. These discussions have gained new currency as well as urgency in the present climate, as they are partnered with a growing realisation that the need for these skills are not matched with the training of them. Having more learning designers locally available to fill the gap means that there should be access to formal tertiary-level education in learning design offered at Australian universities. In review of the curriculum landscape the current approach by institutions thus far is to offer short or one-off subjects (i.e., units of instruction) in the basic courses (Australian Institute of Training \& Development, 2021) that are specific to the use of online technologies in the learning spaces (University of Sydney, 2021), but there are, until now, no Australian university courses (what others may refer to as programs) that explicitly address learning design as a field. This means that Australian universities are poorly prepared to meet the growing demands for learning designers that is predicted (Seek.com, 2020), and this realisation was the starting point for the development of the University of Technolgy's Graduate Certificate in Learning Design (GCLD). Thus investigating What should learning designers learn? as a research and design problem can close this gap with further elaborations on questions that additionally ask the hows, whens and who. And with this acknowledgement these additional questions are intimated through the following narratives.

\section{Reviewing the current state of learning design instruction}

Gray et al (2015) provide a useful overview of the different approaches towards thinking about the work of learning designers and how that has influenced the development of approaches to instruction for learning designers. They begin by stating that, with a few exceptions, such as Smith and Boling (2009), there has been little attention paid to the work done by learning designers in the field and that has led to a requisite lack of theorising about the best ways of training and developing learning designers. However, they note that this has begun to change, and this focus on the work of learning designers has challenged the primacy of the model-first approach to learning design. Studies like Wedman and Tessmer's (1993) show that many expert learning designers do not strictly adhere to any one particular model. Instead, design models are often a starting point for some, (e.g.,mostly novices), but they [the models] are adapted and omitted where appropriate. This finding is supported by Silber's (2007) research, which suggested that learning designers engage in iterative problem solving at every stage of the design 
process. Gray et al., (2015, p. 27) attribute this to the growth of constructivism within design approaches. They write, 'In other words, instructional designers should make decisions based on the constraints in their particular settings' instead of relying on the rigid application of a model. Indeed, as Jonassen (2008) points out, strict adherence to one process often leads to unsuitable outcomes as most learning problems are truly ill-structured.

With a focus explicitly on improving instructional design education, York and Ertmer (2016) examined the practice of expert instructional designers. Leaving aside arguments about what constitutes expertise in this paper (Ertmer et al., 2008; Rowland, 1992; Visscher-Voerman, 1999), York and Ertmer (2016) identified a consensus on 61 different design principles employed by instructional designers. Of the 61 design principles, 32 could be placed within the ADDIE framework, and covered areas like knowing your students and target audience, considering the best use of technology and conducting a pilot if possible. However, the remaining 29 principles covered a range of areas that are often called 'soft skills', including communication, dealing with clients, and project management. These soft skills are often prominent in expectations employers have for learning and instructional designers as Kang and Ritzhaupt (2015) identified, but can be overlooked in training programs for the same. York and Ertmer (2016, p. 187)conclude by arguing that 'because design is a problem-solving process, novices should understand what practicing instructional designers do and what principles they work from, rather than just memorizing steps in a model'.

York and Ertmer (2016) suggest a number of ways this might influence the field of instructional design. In order to move beyond the model and to cover the full range of principles as described above, learning design students could engage in either case based learning scenarios (Ertmer \& Russell, 1995; Ertmer et al., 2013) or real world problem solving (Hartt \& Rossett, 2000). Lowell and Moore (2020) extend this idea by suggesting that learning design instruction should take place in authentic settings. Such an approach means that novice designers are 'steeped in the messiness of real-world problems that they must muck through and negotiate with fellow designers' (Brill, 2016, p. 683). This can be done by:

(1) Modifying the design process in the lesson to make it more authentic, such that students would receive additional feedback at earlier stages, which is reflective of what they would receive in the real-world

(2) The inclusion of a client as a role-player; and

(3) Increasing student support through scaffolding their design and learning process during a real-life project. (Lowell \&Moore, 2020), p. 588)

Another approach is that students could be taught to make use of these skills explicitly, especially in the nature of dealing with ill-structured problems (Jonassen, 2008) as it relates not only to the field but to society at large (Reeves \& Lin, 2020). This can be done in conjunction with authentic learning by providing varying contexts for learning designs (de Alvarez \& Dickson-Deane, 2018; DicksonDeane, 2020; Romero-Hall et al., 2020), or even as part of systemic peer review 
(Brill, 2016). Brill refers to the need to develop adaptive decision making (Klein, 2011). Adaptive decision makers are capable of taking in and analysing relevant data, and then quickly iterate solutions by testing, refining and delivering decisions in practice. Such an approach might encourage what Yanchar and Gabbitas (2011) have described as cognitive flexibility, which they argue is an important skill in professional practice for the field. Other researchers, such as Cross (2011) have suggested that instructional design education should co-opt other design practices, such as studio learning.

The field of instructional design education is one that is rapidly changing; with that in mind, the decision to develop a new graduate certificate is a bold one which presents significant challenges to many course development teams-who themselves practice within the field. In addition to changing ideas about what and how learning designers work in practice, there is also the rapidly changing world of work within and without Australia, and also the challenges posed by the significant contraction of the Australian international student market and its attendant effects on employment within universities (Hare, 2021). These challenges also provide opportunities, and the GCLD was and is intending to capitalise on the sudden increase in technological, and especially blended and online, forms of learning.

\section{Methodology for GCLD course design}

It was important to ensure that this course was designed so that graduates were well positioned to enter the market. This has been a criticism of other, related courses, in that they are far too focused on theoretical considerations, which means that graduates are not well suited to begin work immediately as learning designers. To ensure that the course design was strategically informed, a design-based research method was used to theorise, gather, analyse, design and test with stakeholders iteratively (Barab \& Squire, 2004). The strategic influences originated from the federal and institutional levels as well as from socio-economic needs. Each of these three categories of stakeholders (society, government and institution) were used in tandem with general research methods of course offerings to deliberately guide the justifications for the course design, thus shaping a course that is responsive in its design.

\section{Factors contributing to course design}

The Australian Qualifications Framework (AQF) differentiates the levels of Australian qualifications, including vocational and technical training, all the way up to doctoral qualifications (Australian Government Department of Education, Skills and Employment, 2013). The AQF is a data point that courses must justify as a foundational need and can be used with the socio-economic need for the course. Here at each step, there is an increasing expectation that students should engage with an increased volume of learning and theoretical considerations that relate to current and emerging research. The socio-economic need is expressed through the practical 
considerations as being examined thoroughly elsewhere (Darby \& Lang, 2019), where there is very little homogeneity amongst students entering tertiary institutions. Students today are an increasingly diverse group; while there are still significant numbers of school leavers, there are also people coming to tertiary study after a period of work, changing careers or child-rearing. In addition, those who are studying are increasingly time-poor; many have at least one job (and sometimes two or even three), in addition to caring responsibilities for children or elderly parents. This means that there is increased pressure on universities to provide flexible options for students - all coming at a time when universities are increasingly feeling budgetary constraints themselves (Hare, 2021).

Another factor that influenced the course design was the feedback that was received from industry partners. As stated earlier, there is an increase in the numbers of industries who are now advertising for learning designers. The skills and knowledge exhibited in these ads were already examined so that those industries expecting learning designers (or similarly-titled roles) were accommodated in their expectations of that which was notable more for the diversity of expectations than the similarity. To further develop this idea, 15 interviews with industry personnel were conducted to better inform the development of the course. The interviews focused on the role of education and training within the particular organisation, and the role that learning designers were expected to play in that field. The industries involved included: military, healthcare, education, pharmaceuticals, finance and others. In this way, the research methods here acknowledged Sugar et al (2012), who examined the expectations that employers had of novice instructional designers (and identified the expectancy gap between the employers and the training programs).

Finally,12 interviews were undertaken with educators and learning designers, working in a range of fields. This included learning designers and technology specialists within higher education, at a number of different institutions, and also learning designers and educators working within primary and secondary school systems. These interviews asked general questions about an individual's understanding of the knowledge, skills and abilities of the profession (Eraut, 1994, 2004; Watkins \& Marsick, 1992) and through these interviews, the interviewees helped map out the opportunity space and identify both the constraints and the principles that were wanted as a foreground in the design of the graduate certificate. The analysis of these interviews formulated key design principles for the GCLD and in turn, became the 'in-practice' guidelines for the course. The guidelines yielded considerations to specific content which included flexible course-design, research informed content and practice-based experiences with key insights to building core business skills (Brill, 2016; Gray et al., 2015; Jonassen, 2008; Klein, 2011; Luckin et al., 2013; Silber, 2007; Wedman \& Tessmer, 1993; Yanchar \& Gabbitas, 2011; York \& Ertmer, 2016). More broadly speaking, these ideas also needed to fit within UTS's approach to teaching and learning, and its organisational values and priorities (University of Technology Sydney, 2013) which outlines a practice-oriented learning approach. In many ways, the development of the graduate certificate became a learning design challenge to solve in itself. The key principles are discussed below, and also how 


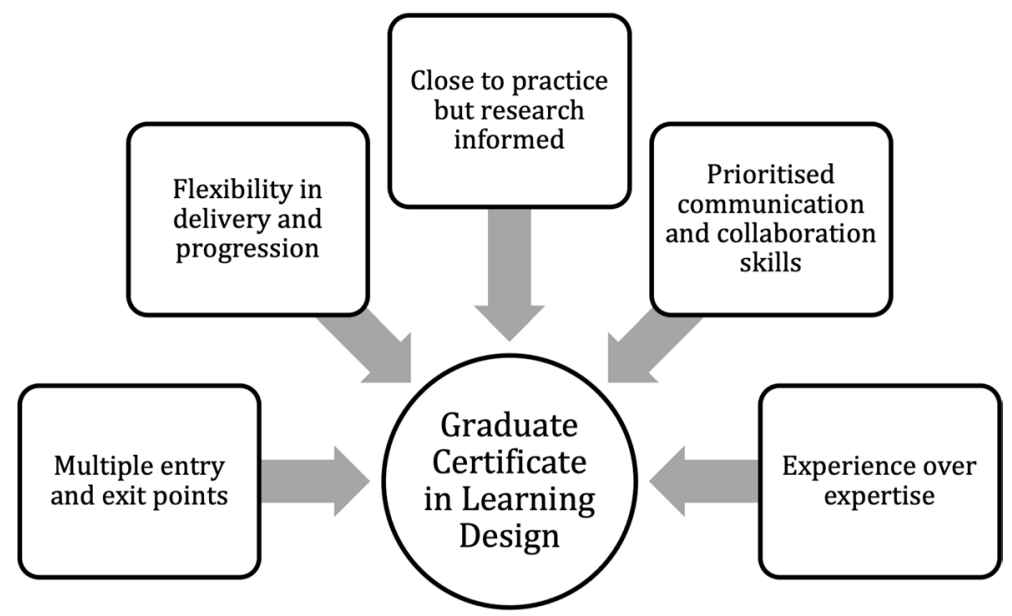

Fig. 1 Key Principles in the development of the graduate certificate in learning design

they developed into 'in-practice' applications of those principles. These principles are presented below (Fig. 1).

\section{Key principles}

\section{Multiple entry and exit points}

The first principle that became immediately apparent, through discussion with the various stakeholders, was the multiplicity of roles in which learning designers required to demonstrate competence (Jonassen, 2008; Klein, 2011). Our initial scoping of the field had identified the vast disparity in different learning design and learning design adjacent roles. Some positions called for a detailed knowledge of specific programming or web design skills, while others focused much more on the development of online applications and learning products. There were some commonalities, too, especially in the need to work collaboratively with subject matter experts and other team members.

What this meant as course designers was the requirement to ensure that any course that was designed, and the subjects that made up that course, had multiple entry and exit points. By this, it is recognised that students enrolled in the subjects and the course would have different expectations and requirements for the course; that is, they would be seeking different content knowledge and skill development. Some students would require a solid theoretical foundation in learning theories and instructional technologies; others might require more focused tuition around the development and application of design-based skills and technologies. Others might be seeking to upskill in a particular area-for example, learning analytics. And then again, some students might require all of these. 


\section{Flexibility in delivery and progression}

Another aspect, closely related to the preceding one, was the need for the course to be flexible in terms of delivery and progression (Wedman \& Tessmer, 1993; Yanchar $\&$ Gabbitas, 2011). While the principle of 'multiple entry and exit points' was more focused on the course as a whole, and the content within, this principle was more granular in that it related to the learning activities and assessment tasks within each subject in the course. This was based on the recognition that the students enrolled in this course would likely have a number of competing life commitments, (e.g., work and caring responsibilities). While this is true of many courses, and perhaps especially post graduate certificates, the fact that this course was being developed in an entirely new setting, and that it was also a course about learning design, meant that ensuring that flexibility was an option throughout the course as well as within the subjects. A number of models were consulted for this, including Beatty's (2019) HyFlex model, which has gained significant popularity during COVID-19. The impact of the pandemic also meant that significant flexibility was required, although the constraints of moving to an online-only environment also provided significant affordances and considerations it needed to be aligned with the strategic objectives.

\section{Close to practice but research informed}

From the first course design conversations, something that all of the design team wanted to balance was the need for the course as a whole, and the individual subjects within it, to be both close to practice and also research informed (Gray et al., 2015; Silber, 2007; York \& Ertmer, 2016). This also developed through conversations, especially with currently practicing learning designers who were quick to point out that often, the practical and technical skills required of learning designers were ignored in favour of developing their knowledge about theory. Alternatively, academics and researchers within the field of learning design (and adjacent fields) identified that practical and technical skills needed to be well supported by an understanding of research, rather than simply existing in isolation, like a vocational qualification.

This point is supported by the Australian Qualifications Framework (AQF) for postgraduate certificates, which states that there is a requirement for students to engage with current and emerging theories related to the field of practice (Australian Government Department of Education, Skills and Employment, 2013). This support of the AQF is also echoed in UTS's (2013) teaching and learning strategy, which states,

At UTS, we prepare students to work long-term in a dynamic and changing professional environment. Students gain exposure to professional practice throughout their degree through experiences such as: internships and practicums.

Therefore, rather than privileging one over the other, one of the design principles that informed the development of the GCLD was the need for the course to be both close to practice and research informed. 


\section{Prioritised communication and collaboration skills}

Through our analysis of job descriptions calling for learning designers and similar positions, a number of common requirements were identified in these roles (York \& Ertmer, 2016). While the most popular was an expectation that the applicant would have some level of expertise and experience in designing and developing training and educational programs, the second most common requirement was for high level communication and collaboration skills. This aspect is easy to overlook in favour of the 'tech' side of things, but to do so would ignore the very important role played by communication in learning design work. Learning designers are often required to work with subject matter experts, especially in the corporate or higher education sectors, and therefore they need to be able to collaborate and communicate effectively in order to develop and maintain a productive relationship. In addition, it is becoming more common for learning designers to work in teams, alongside other kinds of designers, researchers and professional staff. Again, working within this team requires a level of communication and collaboration that is not immediately obvious. While it might be easy to assume that postgraduate students already had these skills, they needed to be explicitly included (i.e., taught) in the GCLD. Therefore, the course in question needed to provide opportunities, not just for students to develop, enhance and/or practice these skills, but also to be assessed on how effective they were at deploying them.

\section{Experience over expertise}

The final, but perhaps most important design principle, was the need for adaptability - to be mindful of the rapidly changing face of technology, and especially societal use and needs of [educational] technologies (Brill, 2016; Wedman \& Tessmer, 1993). A number of the participants in the interviews noted how they had been forced-or decided to-change tools like their Learning Management Systems (LMSs), either out of a desire to make use of the opportunities provided by a new product, or because legacy systems were no longer supported or feasible in the current environment. Broader social changes, such as the move towards mobile technology, meant that older platforms often looked 'clunky' in comparison to newer, mobile-first applications, and also that students were increasingly expecting to be able to access course materials via smartphones and tablets, rather than personal computers. This is even more the case when considering the array of software a learning designer uses in their lifetime of practice. When comparing experienced designers to those new to the profession the ecosystem of tools used can differ from an individual perspective as well as in comparison to tools presumed to be used in the profession (Luckin et al., 2013).

With that in mind, a focus on teaching students more about the kinds of tools that were available, and how they might be used, rather than focusing on any one particular tool to the exclusion of all the others was important. While it might have been tempting to focus on a specific LMS such as Canvas, or a specific suite of tools like Adobe's Creative Cloud, the reality is that not all of the students, when they had graduated, would be working in contexts where they had access to those 


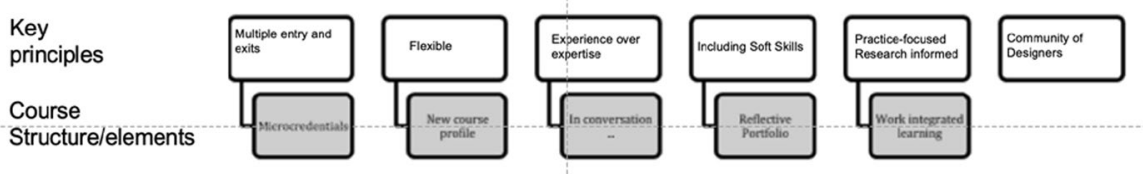

Fig. 2 Design principles in the graduate certificate in learning design

particular tools. Therefore, there was a design decision to develop transferable skills by focussing on experiences with many different kinds of tools, rather than developing expertise in any one tool (Wakefield et al., 2012).

\section{In practice}

These design principles were developed into specific features within the GCLD. The connection between the different points is documented in Fig. 2.

\section{Multiple entry and exit points: microcredentials}

In order to meet the design principle requiring multiple entry and exit points, the decision was made to reduce the size of the subjects (what some in other contexts would refer to as courses) within the graduate certificate, by offering more of them,

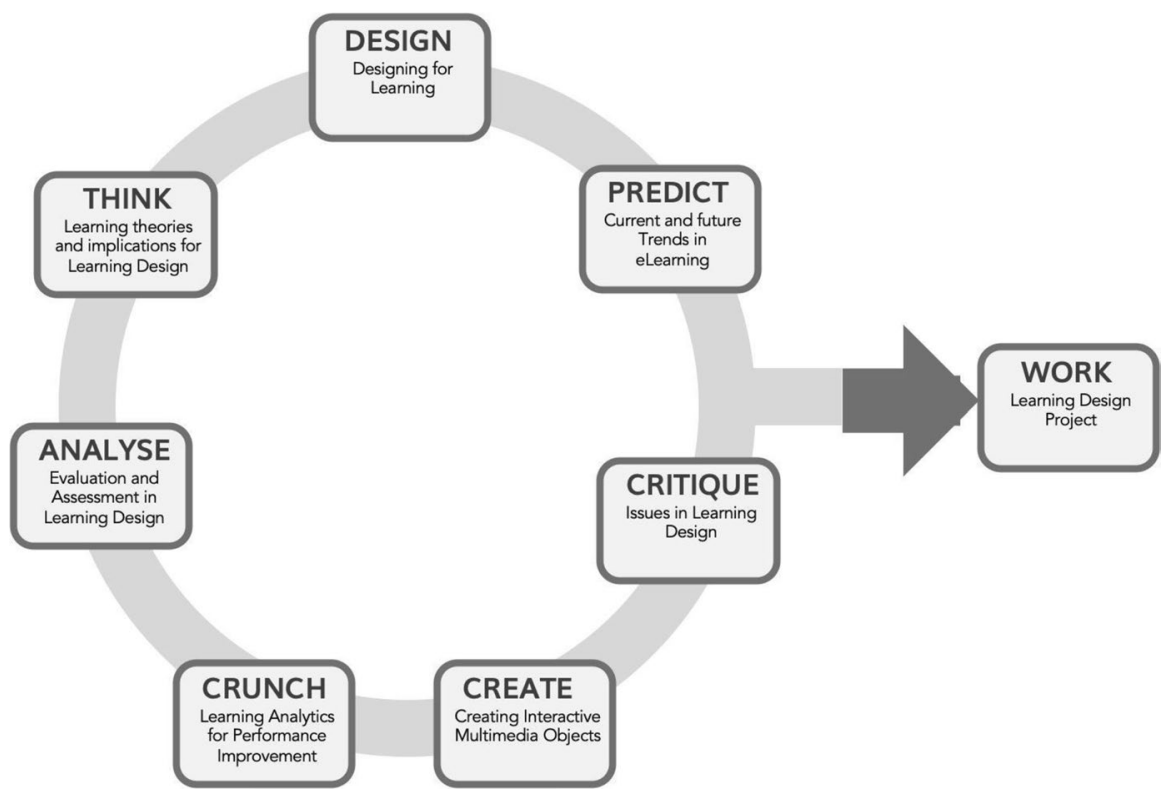

Fig. 3 Subjects included within the UTS Graduate Certificate in Learning Design (GCLD) 
and making all of them available as microcredentials. Normally, subjects at UTS are 6 credit points, which equates to $150 \mathrm{~h}$ of study. However, within the GCLD, each subject is worth 3 credit points, and equates to between 60 and $75 \mathrm{~h}$ of learning. This volume of learning includes any work on assessment tasks, reading and also face to face teaching (when that takes place), but there is no minimum mandated for this. The final subjects are described below (Fig. 3).

\section{Flexibility: new course profile including case studies and expressions sessions}

The requirement for flexibility meant that a different approach to learning than was traditional at UTS was needed. This was hastened by the COVID-19 pandemic, but the basics were in place before the pandemic occurred. In short, students were able to select the nature and level of their participation in the subject. The overall course included the following learning components where each subject include components as needed:

- Online material that could be consumed in an asynchronous manner;

- Active discussion boards and case studies applying key concepts;

- Short explainer videos identifying key concepts;

- Weekly live sessions (which were recorded and could be viewed later);

- Interviews and associated activities with practitioners;

- 'Expression sessions' -interactive workshops showcasing particular techniques or tools.

The expression sessions were a smaller version of the studio based learning advocated for by Cross (2011) and Smith and Boling (2009). With this course design, students could choose which of these sessions they attended and when and how they completed them.

\section{Experience over expertise: in conversation with LD}

A particular focus, as discussed above, was the need to ensure that students developed a breadth of skills, rather than expertise in any one particular method or tool. In order to communicate this to students, practicing learning designers were presented as knowledge points within all subjects in the course. They were interviewed, and these interviews became part of the course material: 'In conversation with a learning designer'. In these conversations, learning designers were asked to reflect upon the way they kept up to date with their profession, and the tools and approaches that they were currently using, no longer used, and might use in the future. By adopting this model, we were seeking to put into practice a connection between the learning of learning design and the practice of learning design — but allowing students to see exactly what and how learning designers worked today with projections to their own future practice (Rowland, 1992). 


\section{Collaboration and communication skills: reflective portfolio}

In order to meet the need for learning designers to develop collaboration and communication skills, the students would contribute to the development of a reflective portfolio throughout the course as a learning outcome which could then be presented to potential employers. As such, each subject in the course had two assessment tasks: the first being the development of a learning design object or material, and the second being a reflection, discussion or commentary about the design choices that they made in creating the object or material. Both of these tasks were added to the student's portfolio as a showcase of skills in the profession, and a reflective-practice narrative which explained their design-decisions. This was an effort to develop the 'soft skills' (Kang \& Ritzhaupt, 2015) that are often overlooked in learning design instruction as well as a response to any potential questions from employers as to the employability of a graduant (Artess et al., 2017).

\section{Close to practice but research informed $\rightarrow$ Work integrated learning}

In order to meet the principle of being close to practice, an internship-like subject into the graduate certificate was implemented. This took place in the subject titled Work: Learning Design Project. Unlike all the other subjects in the course, this subject needed to be completed last, as it was intended to serve as a capstone for the work that students had previously undertaken. In this subject, students either worked within the learning design teams at UTS, or within a similar setting in their own professional context, as learning designers. This was so that they would have the chance to apply their knowledge and skills in an authentic setting; that is, it was meant to serve as the bridge between learning about being a learning designer and a learning designer in practice (Muldoon, 2009; Rowland, 1992; Tripp, 1994; Wakefield et al., 2012).

\section{Building community}

In addition to the five design principles identified above, the design team added a sixth: building community. This was required for two reasons. Firstly, there was a conscious decision to want students to feel that they were joining a profession, rather than just finishing a degree or a qualification (Fortney \& Yamagata-Lynch, 2013; Muljana et al., 2020; North, 2018). Here, building off of Wenger's Community of Practice (1998) through a community of practitioners where there exist varying levels of expertise across industries, there is the ability to grow the knowledge sets leveraging participation levels and interests (Lave \& Wenger, 1990). Based on the move to microcredentials and changing the order in which students could complete the course meant that students would not complete the course in a uniform way. Therefore, in order to engender a sense of community, an optional social media group was established where students were invited to join at the beginning of their learning journey. This group existed outside the university ecosystem-on a wellknown professional social media and networking site. It was used as a way to create a home for alumni but most importantly for students to be permanent members of 
the profession where informal mentoring can take place between those in the field, current students and graduates.

\section{Conclusion and implications for the learning designer-the teacher, designer and student}

Developing this course was a challenging process for the design team involved. The designers were required to work both as teaching and research faculty members and also as learning designers in order to develop a course that best meets the needs of those going into the profession. The needs assessment required the team to prepare students to enter the profession, well-positioned to apply their skills and knowledge in a range of different sectors and industries. By using this course design case study as a problem, the entire endeavour framed how learning design instruction may be operationalised within the Australian higher education context. The result identified key design principles (i.e., multiple entry and exit points, flexibility in course delivery, close to practice, prioritising communication and experience over expertise) to develop a comprehensive and detailed structure for how learning design instruction can be.

Understanding that this is built upon both the extant research from the other contexts, and the specific market and institutional requirements within Australia at the current time, the product is truly representative of the intersection of the era and the expressed intention discussed in many of the cited research. It is important to also note that there must be an acknowledgement to the terminology used and taxonomy of skills and abilities implied, as more terms, skills and abilities are drafted into the field. As the future of the profession is not clear, but as more elements are discovered most certainly positive, there is value in embracing known and potentially unknown factors that may have different meaning to and for a similarly designed course. The final point here is that there will be a need to ensure that the core principles of the field are used to adapt, grow [experiences] and engage others knowing that it must still be grounded in the research that informs this field of learning design.

\section{References}

ANZSCO. (2019). Australian and New Zealand standard classification of occupations (Government Version 1.3). Australian bureau of statistics. https://www.abs.gov.au/ausstats/abs@.nsf/Lookup/1220. 0Chapter22013,\%20Version\%201.3

Artess, J., Mellors-Bourne, R., \& Hooley, T. (2017). Employability: A review of the literature 2012-2016. http://derby.openrepository.com/derby/handle/10545/621285

Australian Institute of Training and Development. (2021). Instructional design-Australian institute of training and development (AITD). Australian Institute of Training and Development (AITD). https:// www.aitd.com.au/instructional-design

Barab, S., \& Squire, K. (2004). Design-based research: Putting a stake in the ground. The Journal of the Learning Sciences, 13(1), 1-14.

Beatty, B. J. (2019). Hybrid-flexible course design. EdTech books. https://edtechbooks.org/hyflex 
Brill, J. M. (2016). Investigating peer review as a systemic pedagogy for developing the design knowledge, skills, and dispositions of novice instructional design students. Educational Technology Research and Development, 64(4), 681-705.

Cross, N. (2011). Design thinking: Understanding how designers think and work. Berg.

Darby, F., \& Lang, J. M. (2019). Small teaching online: Applying learning science in online classes. John Wiley \& Sons.

de Alvarez, M. S., \& Dickson-Deane, C. (2018). avoiding educational technology pitfalls for inclusion and equity. TechTrends, 62(4), 1-9.

Decherney, P., \& Levander, C. (2020, April 24). Inside higher ed. The hottest job in higher education: Instructional designer. https://www.insidehighered.com/digital-learning/blogs/education-timecorona/hottest-job-higher-education-instructional-designer

Deloitte Access Economics. (2015). Growth and opportunity in Australian international education. Deloitte. https:/www2.deloitte.com/content/dam/Deloitte/au/Documents/Economics/deloitte-aueconomicsgrowth-opportunity-australian-international-education-011215.pdf

Dickson-Deane, C. (2020). Where do we go from here. TechTrends, 64(6), 812-813. https://doi.org/10. 1007/s11528-020-00551-y

Eraut, M. (1994). Developing professional knowledge and competence. Falmer.

Eraut, M. (2004). Informal learning in the workplace. Studies in Continuing Education, 26(2), 247-272. https://doi.org/10.1080/158037042000225245

Ertmer, P. A., Quinn, J., \& Glazewski, K. (2013). The ID casebook: Case studies in instructional design (4th ed.). Pearson. http://alec2.tamu.edu/grad_courses/611/modules/Module1/Lesson2/Case_Studi es/casestudy6_clifford.pdf

Ertmer, P. A., \& Russell, J. D. (1995). Using case studies to enhance instructional design education. Educational Technology, 35(4), 23-31.

Ertmer, P. A., Stepich, D. A., York, C. S., Stickman, A., Wu, X., Zurek, S., \& Goktas, Y. (2008). How instructional design experts use knowledge and experience to solve ill-structured problems. Performance Improvement Quarterly, 21(1), 17-42.

Fortney, K. S., \& Yamagata-Lynch, L. C. (2013). How instructional designers solve workplace problems. Performance Improvement Quarterly, 25(4), 91-109.

Australian government department of education, skills and employment. (2013). Australian Qualifications Framework [Text]. https://www.aqf.edu.au/

Gray, C. M., Dagli, C., Demiral-Uzan, M., Ergulec, F., Tan, V., Altuwaijri, A. A., Gyabak, K., Hilligoss, M., Kizilboga, R., \& Tomita, K. (2015). Judgment and instructional design: How ID practitioners work in practice. Performance Improvement Quarterly, 28(3), 25-49.

Hare, J. (2021, March 30). International students won't return until 2022. Australian financial review. https://www.afr.com/work-and-careers/education/international-students-won-t-return-until-202220210330-p57fau

Hartt, D. C., \& Rossett, A. (2000). When instructional design students consult with the real world. Performance Improvement, 39(7), 36-43.

Jonassen, D. H. (2008). Instructional design as design problem solving: An iterative process. Educational Technology, 48(3), 21.

Kang, Y., \& Ritzhaupt, A. D. (2015). A job announcement analysis of educational technology professional positions: Knowledge, skills, and abilities. Journal of Educational Technology Systems, 43(3), 231-256.

Klein, G. A. (2011). Streetlights and shadows: Searching for the keys to adaptive decision making. UK: MIT Press.

Laurillard, D. (2013). Teaching as a design science: Building pedagogical patterns for learning and technology. Routledge. https://doi.org/10.4324/9780203125083

Lave, J., \& Wenger, E. (1990). Situated learning: Legitimate peripheral participation. Cambridge University Press.

Lowell, V. L., \& Moore, R. L. (2020). Developing practical knowledge and skills of online instructional design students through authentic learning and real-world activities. TechTrends, 64(4), 581-590. https://doi.org/10.1007/s11528-020-00518-z

Luckin, R., Clark, W., \& Underwood, J. (2013). The ecology of resources. Routledge Handbooks Online. https://doi.org/10.4324/9780203075227.ch3

Muldoon, R. (2009). Recognizing the enhancement of graduate attributes and employability through parttime work while at university. Active Learning in Higher Education, 10(3), 237-252. https://doi.org/ $10.1177 / 1469787409343189$ 
Muljana, P. S., Luo, T., Watson, S., Euefueno, W. D., \& Jutzi, K. N. W. (2020). Promoting instructional designers' participation in free, asynchronous professional development: A formative evaluation. Journal of Formative Design in Learning, 4(2), 74-87. https://doi.org/10.1007/s41686-020-00044-4

North, C. (2018). SHIFT: Learning designers as agents of change. In A. Correia (Ed.), Driving educational change: Innovations in action. PB PressBooks, pp. 38-51.

Reeves, T. C., \& Lin, L. (2020). The research we have is not the research we need. Educational Technology Research and Development, 68(4), 1991-2001.

Rieber, L. (2018). The proper way to become an instructional technologist. In R. E. West (Ed.), Foundations of learning and instructional design technology: The past, present, and future of learning and instructional design technology. EdTech books. Retrieved from https://edtechbooks.org/lidtfounda tions/proper_way

Rieber, L. (2018). The proper way to become an instructional technologist. Foundations of Learning and Instructional Design Technology.

Romero-Hall, E., Correia, A. P., Branch, R. M., Cevik, Y. D., Dickson-Deane, C., Chen, B., Liu, J. C., Tang, H., Vasconcelos, L., Pallitt, N., \& Thankachan, B. (2020). Futurama: Learning design and technology research methods. In E. . Romero-Hall (Ed.), Research methods in learning design and technology (pp. 206-226). Routledge.

Rowland, G. (1992). What do instructional designers actually do? An initial investigation of expert practice. Performance Improvement Quarterly, 5(2), 65-86.

Seek.com. (2020, October 26). Career-advice. How to become an instructional designer. https://www. seek.com.au/career-advice/role/instructional-designer

Silber, K. H. (2007). A principle-based model of instructional design: A new way of thinking about and teaching ID. Educational Technology, 47(5), 5-19.

Slade, C. (2018). Professionalisation in academic development: Exploring learning designer roles in a changing higher education sector. Advance HE teaching \& learning conference 2018. Advance HE teaching \& learning conference 2018: Teaching in the spotlight: Learning from global communities, Birrmingham, UK.

Smith, K. M., \& Boling, E. (2009). What do we make of design? Design as a concept in educational technology. Educational Technology, 49(4), 3-17.

Sugar, W., Hoard, B., Brown, A., \& Daniels, L. (2012). Identifying multimedia production competencies and skills of instructional design and technology professionals: An analysis of recent job postings. Journal of Educational Technology Systems, 40(3), 227-249.

Tripp, S. D. (1994). How should instructional designers be educated? Performance Improvement Quarterly, 7(3), 116-126.

University of Sydney. (2021). Graduate certificate in learning sciences and technology. The University of Sydney. https://www.sydney.edu.au/courses/courses/pc/graduate-certificate-in-learning-sciencesand-technology.html

University of Technology Sydney. (2013). What students learn. University of Technology Sydney. https://www.uts.edu.au/research-and-teaching/learning-and-teaching/uts-model-learning/what-stude nts-learn

Visscher-Voerman, I. (1999). Design approaches in training and education: A reconstructive study. Universiteit Twente.

Wagner, E. (2011). Essay: In search of the secret handshakes of ID. The Journal of Applied Instructional Design, 1(1), 33-37.

Wakefield, J., Warren, S., \& Mills, L. (2012). Traits, skills, \& competencies aligned with workplace demands: What today's instructional designers need to master. In P. Resta (Ed.), Proceedings of SITE 2012-society for information technology \& teacher education international conference (pp. 3126-3132). Austin, Texas, USA: Association for the Advancement of Computing in Education (AACE). Retrieved June 20, 2021 from https://www.learntechlib.org/primary/p/40070/

Watkins, K. E., \& Marsick, V. J. (1992). Towards a theory of informal and incidental learning in organizations. International Journal of Lifelong Education, 11(4), 287-300. https://doi.org/10.1080/02601 37920110403

Wedman, J., \& Tessmer, M. (1993). Instructional designers decisions and priorities: A survey of design practice. Performance Improvement Quarterly, 6(2), 43-57.

Wenger, E. (1998). Communities of practice: Learning, meaning, and identity. Cambridge University.

Yanchar, S. C., \& Gabbitas, B. W. (2011). Between eclecticism and orthodoxy in instructional design. Educational Technology Research and Development, 59(3), 383-398. 
York, C. S., \& Ertmer, P. A. (2016). Examining instructional design principles applied by experienced designers in practice. Performance Improvement Quarterly, 29(2), 169-192.

Zhou, N. (2020, July 10). Almost $10 \%$ of Australian university jobs slashed during Covid, with casuals hit hardest I Australia news I The Guardian. The Guardian. https://www.theguardian.com/austr alia-news/2020/oct/07/almost-10-of-australian-university-jobs-slashed-during-covid-with-casualshit-hardest

Publisher's Note Springer Nature remains neutral with regard to jurisdictional claims in published maps and institutional affiliations. 